\title{
Organisational Culture and Dynamics
}

Hillary Odiakaose ODOR

PhD Candidate, Department of Business Administration, Faculty of Management Sciences, University of Benin, Benin City, Nigeria

\begin{abstract}
Every organisation has something unique about the way it operates. It is that uniqueness that every other organisation uses as a mark of distinction in describing that organisation. The ways an organisation operates, with special reference to its beliefs, values and assumptions is what I have conceptualized as organisational culture. The culture of an organisation, to a very large extent, determines the performance of the individuals that work in that organisation and by extension, the organisational performance. This paper takes an in-depth review of the relationships between some organisational culture parameters and individual performance, organisational performance and sustainability. From the extant literature, it still stands to reason that organisations should focus on those aspects of their cultures that are positive in outlook and yield the greatest positive result in terms of individuals and organisational outcomes. On the other hand, they should do away with those aspects of their culture, which are not adding any intrinsic or extrinsic value to their bottom-line. This study totally supports the evidence that managing your organisational culture effectively will lead to a higher organisational performance.
\end{abstract}

Keywords: organisational culture, organisational outcomes, strong organisational culture, weak organisational culture

\section{Introduction}

An understanding of culture is very important for anyone who is interested in the study of organisational growth and development because it gives an organisation a strong competitive advantage. The significance of culture is not being determined by whether there is an existence of soft or complicated culture (Alvesson, 2002); what is paramount is that there is the existence of a corporate culture that guide behaviours and actions within a group.

Kotter and Heskett (2011) give a lucid analysis of how organisational culture positively or negatively affects the economic performance of an organisation. "It is only recently that researchers and management practitioners started looking at organisations as institutions that are being affected by an independent variable that affects employee work attitude and behaviour" (Owoyemi, \& Ekwoaba, 2014, p.168). This paper seeks to examine the construct of culture as it relates to organisation and its effectiveness by looking at the various dimensions of culture as well as the characteristics of culture. Finally, some previous studies investigating the relationship between organisational culture, as an independent variable and other variables are examined.

\section{What is culture?}

Getting a universally acceptable definition of culture has been a very difficult exercise for both management scholars and practitioners. In fact, one authority summarized the predicament of having a generally accepted definition of culture as follows: "Despite a century of efforts to define culture adequately, there was in the early 1990s, no agreement among anthropologists regarding its nature" (Apte (1994, p. 2001).

According to Schein, culture is the pattern of basic assumptions that a given group has invented, discovered, or developed in learning to cope with its problems of external adaptation and internal integration, and that have worked well enough to be considered valid, and, therefore to be taught to new members as the correct way to perceive, think, and feel in relation to those problems"

(As cited in Sun, 2008, p. 138). Culture is "the collective programming of the mind which distinguishes the members of one 
group or category of people from another" (Hofstede 1994, p. 5). "Culture consists of the derivatives of experience, more or less organized, learned or created by the individuals of a population, including those images or encodements and their interpretations (meanings) transmitted from past generations, from contemporaries, or formed by individuals themselves" (Spencer-Oatey, 2012, p. 2). In another way, but flowing from similar angle, the same author sees culture as "a fuzzy set of basic assumptions, values, orientations to life, beliefs, policies, procedures and behavioural conventions that are shared by a group of people, which influence (but do not determine) each member's behaviour and his/her interpretations of the 'meaning' of other people's behaviour" (SpencerOatey, 2012, p. 2).

Cameron (2003) posits that "culture is an enduring slow to change, core characteristics of an organisation" (as cited in Owoyemi, \& Ekwoaba, 2014 , p.168). Schein (1990) went on to say that "culture is manifested at different layers of depth: observable artifacts, values, and basic underlying assumptions" (p.111). According to him, artifacts include things as dress code, physical settings of the office, and the way and manner people address one another. However, in all the above definitions, one very important common denominator is the fact that culture is shared and learned.

\section{Concept of Organisational Culture}

Serpa (2016) sees organisational culture as "a shared way of being, thinking and acting in a collective and coordinated people with reciprocal expectations" (p. 51).

Organisational culture is "the set of shared values, beliefs and norms that influence the way employees think feel and behave in the workplace" (Agwu, 2014, p. 1)

Collins and Porras (2000) opine that organisational culture refers to a system of shared meaning held by members that distinguish one organisation from other organisations.

Organisational culture is as "an informal, shared way of looking at an organisation and membership in the organisation that binds members together and influences what they think about themselves and their work" (O'Donnel \& Boyle, 2008, p.19). Schein (2009) defines organisation culture as collective behaviour of people in an organisation, while Gathai, Ngugi, Waithaka and Kamingi (2012) look at organisational culture in terms of the "leadership styles and the dominant values and beliefs, both conscious and unconscious, dress codes, job titles, among others in an organisation" (as cited in Onyango, 2014, p. 205). Maseko (2017) viewed organisational culture as “a company's orientation towards its internal stakeholders, which forms the basic rules that guide employees' behaviours, developed and shared within an organisation" (p. 3). Schein (2004) argued that "perhaps the most interesting part of culture as a concept is that it points us to phenomena that below the surface are powerful in their impact but invisible, and to a considerable degree, unconscious to people" (p. 8) "Organisational culture is made up of more 'superficial' aspects such as patterns of behaviour and observable symbols and ceremonies, and more deep seated and underlying values, assumptions and beliefs" (O'Donnel \& Boyle, 2008, p. 6).

Although there is no agreement in the literature concerning organisational culture, one authority argued that "there is only one consensus and that is the fact that organisational culture has both tangible and non-tangible aspects" (Sokro, 2012, p. 4).

\section{Characteristics of Organisational Culture}

(Trice and Beyer, (2002), cited by Loisch, 2007, and further cited by Himmer, 2013)

Collective: It is assumed that cultures are not created by individuals alone, but as a result of collective actions. Belonging to a culture involves believing in what the group believes and handling things the way and manner they handle them.

Emotional: The substance and forms of culture are filled with emotions as well as meanings, which is why they help to manage and overcome anxieties. Members of a group seldom doubt the core values and attitudes of the organisational culture.

Historic: Cultural phenomena are connected to the history of the organisation and its traditions and cannot be separated or changed rapidly.

Symbolic: Symbols are on the one hand, a specific type of cultural form, but on the other hand, they are the most general and persuasive form of culture. Furthermore symbols are not directly seizable, but have to be interpreted in order to understand their meaning. 
Dynamic: Even though culture is connected to the organisation's history it still is not static, but rather dynamic. Culture is subject to continuous change.

Diffuse:The more complex the circumstances are, the more diffuse the elements of organisational culture will get.

Robbins and Judge (2011) examine seven basic characteristics of organisational culture: Innovation and risk taking; Attention to detail; Outcome, People orientation; Team orientation; Aggressiveness; and Stability. Robbins and Judge (2000) also state that "the aftermath from the above, sets the foundation for the shared feelings, and how tasks should be performed in the organisation." (p.560). They went further to say that each of the seven characteristics exist on a continuum from high to low and that approaching an organisation on the basis of the above characteristics, then gives a composite picture of the organisational culture

\section{Concept of strong or weak organisational culture}

Organisational culture can either be a strong one or weak one (Deal \& Kennedy, 1982). The type of culture adopted by an organisation is dependent on the extent to which members adapt to that culture" (Maseko, 2017, p. 5). A strong culture exists when every member of the organisation agrees and follows the agreed pattern of behaviour that has proven to be beneficial, both in content and context, to the whole organisation. According to Ashipaoloye (2014), a weak organisational culture, refers to values and beliefs not strongly and widely shared within the organisation. Karlsen (2011, p.112) states that "cultures where employees' goals are aligned to the organisation's goals are often thought of as successful cultures." In an organisation with a weak culture, employees only adhere to organisational rules and regulations not because they derive satisfaction from their jobs, but because of fear of the consequences of their inactions (Maseko, 2017, p. 4). In the opinion of Owoyemi and Ekwoaba (2013, p. 175), strong culture is a "two edged sword that can affect both management and the employees." They therefore advised that positive strong culture should be encouraged while negative strong culture should be discouraged. Alkailani, Azzam, and Athamneh (2012) state that organisational culture can encourage employees to give out their best for the sake of organisational goals, or it can discourage or demoralize them with a subsequent disadvantage to the organisation's survival. Several studies support the preposition that organisations with strong cultures perform better than those with weak cultures. For instance, Onyango ( 2014) states that weak cultures are usually associated with autocratic managers whilst strong cultures are products of collaboration that arises when employees share certain beliefs and value systems with the significant others. In his own final submission, Maseko (2017) concluded by stating that "strong organisational cultures are more successful than weak organisational cultures in achieving organisational goal due to the perceived correlation between organisational culture and employee motivation. This is because organisations with strong cultures have more unity among employees as they hold common beliefs and values" (p. 5).

Robbins and Judge (2000) have this to say about strong and weak culture: "A strong culture will exert more influence on an employee than a weak culture. Therefore, if the culture is strong and support high ethical standard it will have a very powerful and positive influence on employee behaviour. On the other hand, a strong culture that encourages pushing the limits can be a powerful force in shaping unethical behaviour" (p. 600). For instance, some commercial banks in Nigeria that set outrageous deposit targets for its marketing staff are indirectly encouraging them to go into unethical practices in order to get the deposits. "A positive and strong culture can make an average individual perform and achieve brilliantly whereas a negative and weak culture may demotivate an outstanding employee to underperform and end up with no achievement" (Ahmed, 2012, p. 51).

Similarly, Saffold (1998) notes that "strong culture has a powerful influence in improving the contribution made by each employee, either working independently or as a member of a team. Strong culture enhances self confidence and commitment of employees and reduces job stress and improves the ethical behavior of the employees" (as cited in Shazad, \& Luqman, 2012, p. 981).

\section{Model of organisatinal culture}

Organisational culture has the following components: values, artifacts, symbols and 
assumptions (Hatch, 1993). When these components interact with each other, it brings about different outcomes. The interactions of value and assumption are facilitated through manifestation. The interaction between value and artifacts is facilitated through realization. The interaction between artifacts and symbols is done through symbolization. The interaction of symbols and assumptions is facilitated through interpretation.

\section{Dimensions of Organisational Culture.}

From the sociology and management literature, different classification of organisational culture has evolved. According to Muthoni (2013, p. 204), "organisation culture can be classified in terms of adaptability, bureaucratic, mission, and entrepreneurial." Onyango (2014) argues that "adaptability culture is flexible in approach to the change process in meeting the demands of the external environment, while bureaucratic culture is centered on the rituals performed by leaders in the organisation that leads to sustainable transformation process." (p. 9)

Another authority identifies two dimensions of organisational culture, namely participative and manipulative. In a manipulative culture, what the individuals have at the back of their mind is the need to acquire power by any possible means. On the other hand, in a participative culture, the individuals seek to be self actualized and be at peace with others (Trpathi, Kapoor, \& Tripathi, 2000). It may be deduced therefore from the above that if an organisation develops a participative culture, its members will feel proud to be associated with that organisation and as well be involved in the planning and implementations of its strategic initiatives that will bring about growth. On the other hand, in an organisation that has the characteristic of a manipulative culture, people will be loyal towards the organisation, but there is total lack of involvement and commitment, hence they do not have the tendency to behave like good citizens of that organisation. This is true since loyalty without involvement and commitment will lead an organisation to the path of failure.

\section{Hofstede's Cultural Dimensions}

(Hofstede, 1980, p. 13) identified five universal values patterns that vary as influence in each country: individualism, masculinity, power distance, uncertainty avoidance, and long-term orientation. He labeled the above-mentioned dimensions as national culture values. According to him, "national culture was primarily based on differences in values which were learned during early childhood. These values were strong enduring beliefs, which were unlikely to change throughout the person's life" (Abu-Jarad, Yusof, \& Nikbin, 2010, p. 36). According to Hofstede, history is the source of values, identity and institutions'regulations and under condition of relativism we can identify some cultural dimensions:

1. Power distance is the measurement on which a society accepts unequal distribution of power of people and organisations. 2. Individualism/collectivism: the degree of responsibility in actions for individuals or groups. 3. Masculinity/femininity: the extent to which the social and emotional traits are allocated to different gender. 4. Uncertainty avoidance: the level of acceptance given by the threat of uncertainty and ambiguity and as consequence avoidance in such situations. 5. Long-versus short-term orientation: the size of social, material and emotional need from a society to program its members to accept delayed satisfaction" as cited in (Vacile, \& Nicolescu, 2016, p. 37)

\section{Methods of Learning Culture}

According to Brown (1998), as cited in (Ahmed, \& Shafiq, 2014, p. 23), there are nine ways of learning an organisation's culture: "Arte facts, Language, Behaviour patterns; Norms of behaviour; Heroes; Symbols and symbolic action; Believes, values and attitudes; Basic assumptions; and History" (Ahmed, \& Shafiq, 2014, p. 23.)

\section{Importance of Organisational Culture.}

Some researchers have discovered that there are some cultural traits that relates with economic performance (Denison, 1990). "Organisational culture is one of the most important factors that impact on organisational performance" (Ahmed, \& Shafiq, 2014, p. 22). They argued further, that "the notion of organisational performance is affiliated to the endurance and success of any organisation." (Ahmed, \& Shafiq, 2014, p. 22).

According to Divyarajaram (2014), organisational culture is important in promoting code of conduct in employees, facilitates motivation though 
recognition, promotes self satisfaction, and acts as a guide to employee thinking and actions.

Schein (2011) identified four functions of organisational culture: providing a sense of identity to members; improving the readiness of members and strengthening organisational values; and shaping behaviour through a control mechanism" as cited in (Ahmed, \& Shafiq, 2014, p. 23). Organisational culture "is not just for a competitive advantage, it has become a sine qua non for organisational success, allowing companies to attract and retain top employees" (Sadri \& Lees, 2001, p. 858.)

Organisational culture that is "manifested in beliefs and assumptions, values, attitudes and behaviours of its members is a valuable source of firm's competitive advantage" (Ehtesham, Muhammad, \& Muhammad, 2011, p. 79).

"Organisations are social glues that bond employees together, makes them feel as part of the organisation thereby bringing out the best in them in terms of efficiency and effectiveness in achieving organisational goal." (Fakhar, 2005, p. 981).

In an empirical study on the effects of organisational culture on change management, it was discovered that "organisational beliefs, employee attitude and value system, as part of organisation culture, has an impact on change management" (Onyango, 2014, p. 204).

$\mathrm{He}$ therefore recommended that organisation should ensure that they openly support employee attitudes and pattern of work that promotes change management. This, according to him, will enhance the corporate culture that sustains economic development and prosperity of the organisation (Onyango, 2014, p. 204)

Agrawal and Tyagi (2010) note that "a clear understanding of organisational culture is important for all organisational managers and leaders because it influences the way their companies react to the dynamic challenges faced by the business organisations." (p. 60)

In other words, successful managers are those that adhere strictly to the ways things are done in their dynamic organisations. One of the key drivers to a good knowledge management's strategy is ensuring that an organisation embeds rich cultural values into its vision and mission, because knowledge management can be used to develop an innovative culture" (Agrawal, \& Tyagi, 2010, p. 71).
Similarly, Yildiz (2014), writing on the relationship between organisational culture and organisational performance, demonstrated that knowledge management and innovative strategy, which, according to him, are features of organisational culture, have significant impact on organisational performance. However, Kotter and Heskett (2011) assert that even those cultures that work well with a company's strategy and business context may not promote excellent performance in the long run, unless they are backed up with strategies and practices that continuously respond to the dynamic environments. However, "the literature suggest that there is an ambiguity in terms of the link with organisational performance as strong cultures have been shown to hinder performance (unadaptive) and there is also a problem of isolating the impact of corporate culture on performance." (O'Donnel and Boyle (2008, p. 14).

Employees will experience a higher level of motivation given a good organisational culture. It goes to say therefore that when organisations have a strong culture that appreciates the contributions of employees through monetary and non monetary rewards, such act will be reciprocated and lead to an increase in motivation and subsequently an increase in performance.

Ahmed and Shafiq (2014) concluded by saying that "organisational culture is the most important variable that influences organisational performance." (p. 22)

Awadh and Saad, (2013) state that "culture and performance were considered competitive advantage of an organisation, which is attained through strong association and establishment of culture and that organisation culture helps in internalizing joint relationship that helps to manage effective organisation processes" (p. 172) According to O'Donnel and Boyle (2008), "an understanding of organisational culture and cultural types helps our understanding of why managerial reforms may impact differently within and between organisations." (p. 10). Zalami (2005), on the other hand, notes that an existing good culture that is properly aligned with goals and objectives of a transformation agenda will surely be an aid to any major institutional transformation.

Agrawal and Tyagi, (2010), are of the opinion that "culture can be a great attracter for talent, especially those who are professionally qualified." (p. 84) 
It is important to understand the elements that attract, retain and engage employees. Successful implementation of a positive corporate culture, with strong values can be a powerful human resource strategy, whose importance will be growing continuously.

Jones et al. (2005) demonstrated that organisational culture is a source of knowledge since it enables employees to create, acquire, share and manage knowledge. Organisational culture has a strong bond with the competitive performance of a company. "Some authors even agree that performance comes from interdependent behavior like cooperation, knowledge sharing and mutual assistance." (Tseng, 2010), (as cited in Yildiz, 2014, p. 54).

The research on the impact of culture on organisational performance is mixed, however, depending on how the research is done and what variables are measured (Griffin, 2012).

Maseko (2017), in discussing the impact of culture on employee motivation, noted that "nonmotivated employees, generally portray a dissatisfied attitude to work, hence are less committed, and are more likely to quit the organisation" (p. 2)

Perters and Waterman (1982) in their write up on the relationship between organisational culture and performance, assert that "high performance firms could be distinguished from low performance firms because the former possessed certain cultural traits and "strong culture" The same view was held by Deal and Kennedy, (1982), who suggested that organisational performance can be enhanced by strong shared value" (as cited by Abu-Jarad, Yusuf, \& Nikbin, 2010, p. 41). Furthermore, Agwu (2014), writing on organisational culture and employee performance in National Agency for Food, Drug administration and Control (NAFDAC), concluded that "there is a significant relationship between organisational culture and increased employees' commitment in NAFDAC" (p. 9). Based on this finding, he advised that the agency should sustain that prevailing culture of decentralization because it facilitates decision making and brings about fluidity in times of turbulence.

While investigating the effects of organisational culture on organisational performance in the hospitality industry, Chilla, Kibet, and Douglas (2014), note that some components of organisational culture are positively and significantly correlated to organisational performance. They also observed that there is a significant correlation and predictability of control systems, organisation structure and rituals on organisational performance.

Similarly, Shahzad, Iqbal, and Gulzar (2013) observe that culture of an organisation has a significant positive impact on employees' job performance in selected software companies in Pakistan.

Aluko (2003), using qualitative and quantitative techniques with a sample size of 630 employees, investigated and found out that employees attitude and beliefs significantly affect organisation performance, as cited in (Onyango, 2014, p. 204). When organisation members identify with the culture, the work environment tends to be more enjoyable, boosting morale. This leads to increased levels of team work, sharing of information and openness to new ideas." as cited in (Agrawal, \& Tyagi, 2010, p. 13).

\section{Conclusion}

Culture has been defined as a way of life of a group of people. It is concerned with how employees perceive the characteristics of their organisation, not with whether they like them or not. In a nutshell, the importance of organisational culture as an organisational variable of analysis cannot be overemphasised. Organisational culture plays a significant role in motivating employees.

The question of whether a culture is strong or not, does not arise, rather what is important is that strong and positive cultures should be encouraged, while strong culture, with negative consequences, should be discouraged. In other words, we should only encourage those aspects of the culture that will help to shape high ethical standards among employees. This, in turn, will bring about high productivity among employees and on the aggregate bring about increased organisational performance.

\section{References}

1. Abu-Jarad, I.Y., Yusuf, N., \& Nikbin, D. (2010). A review paper on organisational culture and organisational performance. International Journal of Business and Social Science, 1(3), 26-46.

2. Agrawal, R.K., \& Tyagi, A. (2010). Organisational culture in Indian organisations: An empirical study. International Journal of Indian Culture and Business Management, 3(1), 102-110. 
3. Agwu, M.O. (2014). Organisational culture and employees' performance in the National

4. Agency for Food and Drugs Administration and Control (NAFDAC) Nigeria. Global Journal of Management and Business Research, 14(2), 1- 9.

5. Ahmed, S. (2012). Impact of organisational culture on performance management practices in Pakistan. Business Intelligence Journal, 5(1), 50-55.

6. Ahmed, M. \& Shafiq, S. (2014). The impact of organisational culture on organisational performance: A case study of telecom sector. Global Journal of

7. Management and Business Research: Administration and Management, 14(3), 22-29.

8. Alkailani, M., Azzam, I.A., \& Athamneh, A.B. (2012). Replicating Hofstede in Jordan: Ungeneralized, reevaluating the Jordanian culture. International Business Research, 5(4), 71-80.

9. Alvesson, M. (2002). Understanding organisational culture. New Delhi: Sage.

10. Apte, M. (1994). Language in sociocultural context. In: R. E. Asher (Ed.), The Encyclopedia of Language and Linguistics. 4, 2000-2010). Oxford: Pergamon Press.

11. Ashipaoloye, F.K. (2014). A Comparative analysis of the organisational culture and employee's motivation of selected cities in Calabar zone: Basis for employee's motivation, leadership and innovative management. Asia Pacific Journal of Multidisciplinary Research, 2(5), 54-63.

12. Awadh, A.M., \& Saad, A.M., (2013). Impact of organisational culture on employee performance. International Review of Management and Business Research, 2(1), 167-180.

13. Balan, S.A., \& Vreja, L.O. (2013). The Trompenaars' seven dimension cultural model orientations of Romanian students in management. Proceedings of the $7^{\text {th }}$ International Management Conference "New Management for the New Economy" November 7 th- $8^{\text {th }}$. Ucharest, Romania.

14. Chilla, H.A., Kibet, Y., \& Douglas, M. (2014). Effects of organisational culture on organisational performance in the hospitality industry. International Journal of Business and Management Invention, 3(1), 67-86.

15. Goffee, R., \& Jones, G. (1996). "What holds the modern company together?" Harvard Business Review, 74(6), 853-859.

16. Dasanayake, S. W. S. B. \& Mahakalanda, I. (2008). A literature survey on organisational culture and innovation. Global Business and Management Research, Boca Raton, Florida. 539-550.

17. Deal, T. E., \& Kennedy, A. A. (2000). The new corporate cultures: Revitalizing the work place after downsizing, mergers and reengineering, London, UK.Texere Publishing Limited.

18. Deal, T.E., \& Kennedy, A., (1982). Corporate culture, the rite and ritual of corporate life. Reading: M.A Addison Wesley.

19. Denison, D.R. (1990). Corporate culture and organisational effectiveness. New York: Wiley.

20. Divyarajaram (2014). Functions of organisational culture. Author Stream. Retrieved from www.authorstream.com/presentation/divya rajaram-1390912-functions-oforganisational culture/

21. Ehtesham, U.M., Muhammad, T.M., \& Muhammad,S.A. (2011). Relationship between Organisational culture and performance management practices: A case of University in Pakistan. Journal of Competitiveness, 4.

22. Fakhar et al (2012). Impact of organisational culture on organisational performance: An over View. Interdisciplinary Journal of Contemporary Research in Business, 3(9), 975-985

23. Greenberg, J., \& Baron, R.A. (1995). Behaviour in organisations. New Jersey: Prentice Hall.

24. Handy, C. (1993). Understanding organisations, 4th ed., London: Penguin Books Ltd.

25. Hofstede, G. (1991/1994). Cultures and organisations: Software of the Mind. London: HarperCollinsBusiness.

26. Himmer, N.S. (2013). How does organisational culture influence the performance of luxury hotels based on the example of the Ritz--Carlton Hotel 
Company L.L.C.? Retrieved from https://www.modul.ac.at/uploads/files/The ses/Bachelor/Thesis-2013-

Himmer_Thesis.pdf

27. Hofstede, G., Hofstede, G. J., \& Minkov, M. (2010). Cultures and Organisations: Software of the Mind: Intercultural Cooperation and its Importance for Survival. USA: McGraw--Hill.

28. Joiner, T.A. (2000). The influence of national culture and organisational culture alignment on job stress and performance: Evidence from Greece. Retrieved from http://www.emerald-library.com/ft

29. Kotter, J. P., \& Heskett, J.L. (2011). Corporate culture and performance. New York: Free Press.

30. Loisch, C. U. (2007). Organisationskultur als Einflussgröße der Export Performance. Wiesbaden: Deutscher Universitäts--Verlag.

31. Lustig, M. W., \& Koester, J. (1999). Intercultural competence, interpersonal communication across cultures, 3rd.ed. New York: Longman.

32. Maseko, S.B.T. (2017). Strong vs. weak organisational culture: Assessing the impact on employee motivation. Arabian Business Management Review 7: 287.

33. doi: $10.4172 / 2223-5833.1000287$

34. O'Donnell, O., \& Boyle, R. (2008). Understanding and managing organisational culture. Dublin, Ireland: Institute of Public Administration.

35. Onyango, W.P. (2014). Effects of organisation culture on change management: A case of the Vocational Training Centre for the Blind and Deaf Sikri. European Journal of Business and Management, 6(34), 204-214.

36. Owoyemi O. O., \& Ekwoaba J.O. (2014). Organisational culture: A tool for management to control, motivate and enhance employees' performance. American Journal of Business and Management 3(3), 168-177. doi: $10.11634 / 216796061403514$

37. Perters and Waterman (1982). In search of excellence. Journal of Organisational Behaviour, 6(3), 246-247. doi: 10.1002/job.4030060311
38. Robbins, S. P., \& Judge, T.A. (2011). Organisational Behavior, 14th Edition. New Jersey: Pearson Education, Inc.

39. Sadri, G., \& Lees, B. (2001). Developing corporate culture as a competitive advantage. Journal of Management Development, 20(10), 853-859. Retrieved from

http://www.mcbup.com/research_registers

40. Schein, E. (2009). Organisational culture and leadership. San Fransisco : Jossey Bass.

41. Schein, E.H. (2004). Organisational culture and leadership, $3^{\text {rd }}$. edition, San Francisco: Jossey-Bass.

42. Serpa, S., (2016). An overview of the concept of organisational culture. International Business Management Journal, 10(1), 51-60.

43. Shahzad, F., \& Luqman, R.A. (2012). Impact of organisational culture on organisational performance: An overview. Interdisciplinary Journal of Contemporary Research in Business, 3(9), 112-130.

44. Shahzad, F., Iqual, Z., \& Gulzar, M. (2013). Impact of organisational culture on employees' job performance: An empirical study of software houses in Pakistan. Journal of Business Studies Quarterly, 5 (2), 56-64.

45. Sun, S. (2008). Organisational culture and its themes. International Journal of Business and Management, 3(12), 137141.

46. Szczepańska-Woszczyna, K. (2014). The Importance of organisational culture for innovation in the company. Forum Scientiae Oeconomia 2: 2-39.

47. Sokro, E. (2012). Analysis of the relationship that exists between organisational culture, motivation and performance: Problems of management in the $21^{\text {st }}$ century, $3,106-118$.

48. Spencer-Oatey, H. (2012). What is culture? A Compilation of quotations. Global PAD Core Concepts. Retrieved from

http://go.warwick.ac.uk/globalpadintercult ua

49. Tripathi, S., Kapoor, A., \& Tripathi, N. (2000). Organisational culture and organisational commitment. Indian 
Journal of Industrial Relations, 36(1), 2440.

50. Trompenaars, F., \& Hampden-Turner, C. (1997). Riding the waves of culture: Understanding cultural diversity in business. London: Nicholas Brealey Publishing Limited.

51. Vacile, A.C., \& Nicolescu, L. (2016). Hofstede's cultural dimensions and management in corporations: Theoretical article Case study. Cross-Cultural Management Journal, 18(9), 35-46. Retrieved from: http://seaopenresearch.eu/Journals/articles/ CMJ_9_5.pdf

52. Yildiz, E. (2014). A Study on the relationship between organisational culture and organisational performance and a model suggestion. International Journal of Research in Business and Social Science, 3(4), 103-110. Retrieved from: http/www.ssbfnet.com

53. Zalami, A. (2005). Alignment of organisational cultures in the public and private sectors. Presentation at the meeting of excellence in public service, Amman, Jordan in September. Retrieved from: http://ijqr.net/journal/v11-n3/11.pdf

54. Zhang, X. (2009). On how organisation culture impact on performance and competitiveness. Hubei University of Technology. P.R. China. Retrieved from: 2009cjdh4z95.pdf 